\title{
The Suitability of Methylene Blue Discoloration (MB Method) to Investigate the $\mathrm{Fe}^{0} / \mathrm{MnO}_{2}$ System
}

\author{
Viet Cao ${ }^{1}\left(\mathbb{D}\right.$, Ghinwa Alyoussef ${ }^{2}$, Nadège Gatcha-Bandjun ${ }^{3}$, Willis Gwenzi ${ }^{4} \mathbb{D}$ and Chicgoua Noubactep ${ }^{2,5,6, *(\mathbb{D})}$ \\ 1 Faculty of Natural Sciences, Hung Vuong University, Nguyen Tat Thanh Street, \\ Viet Tri 35120, Phu Tho, Vietnam; caoviet@hvu.edu.vn \\ 2 Angewandte Geologie, Universität Göttingen, Goldschmidtstraße 3, D-37077 Göttingen, Germany; \\ ghenwa_alyousef@yahoo.com \\ 3 Department of Chemistry, Faculty of Science, University of Maroua, BP 46 Maroua, Cameroon; \\ nadegegatcha@yahoo.fr \\ 4 Biosystems and Environmental Engineering Research Group, Department of Soil Science and \\ Agricultural Engineering, University of Zimbabwe, P.O. Box MP167, Mt. Pleasant, Harare, Zimbabwe; \\ wgwenzi@yahoo.co.uk \\ 5 Centre for Modern Indian Studies (CeMIS), Universität Göttingen, Waldweg 26, 37073 Göttingen, Germany \\ 6 Department of Water and Environmental Science and Engineering, Nelson Mandela African Institution of \\ Science and Technology, P.O. Box 447, Arusha, Tanzania \\ * Correspondence: cnoubac@gwdg.de
}

Citation: Cao, V.; Alyoussef, G.; Gatcha-Bandjun, N.; Gwenzi, W.; Noubactep, C. The Suitability of Methylene Blue Discoloration (MB Method) to Investigate the $\mathrm{Fe}^{0} / \mathrm{MnO}_{2}$ System. Processes 2021, 9, 548. https://doi.org/10.3390/pr9030548

Academic Editor: José A. Peres

Received: 22 February 2021

Accepted: 15 March 2021

Published: 19 March 2021

Publisher's Note: MDPI stays neutral with regard to jurisdictional claims in published maps and institutional affiliations.

Copyright: (c) 2021 by the authors. Licensee MDPI, Basel, Switzerland. This article is an open access article distributed under the terms and conditions of the Creative Commons Attribution (CC BY) license (https:/ / creativecommons.org/licenses/by/ $4.0 /)$.

\begin{abstract}
The typical time-dependent decrease of the iron corrosion rate is often difficult to consider while designing $\mathrm{Fe}^{0}$-based remediation systems. One of the most promising approaches is the amendment with manganese dioxide $\left(\mathrm{Fe}^{0} / \mathrm{MnO}_{2}\right.$ system). The resulting system is a very complex one where characterization is challenging. The present communication uses methylene blue discoloration ( $\mathrm{MB}$ method) to characterize the $\mathrm{Fe}^{0} / \mathrm{MnO}_{2}$ system. Shaken batch experiments $(75 \mathrm{rpm})$ for 7 days were used. The initial MB concentration was $10 \mathrm{mg} \mathrm{L}^{-1}$ with the following mass loading: $\left[\mathrm{MnO}_{2}\right]=2.3 \mathrm{~g} \mathrm{~L}^{-1}$, [sand $]=45 \mathrm{~g} \mathrm{~L}^{-1}$, and $0<\left[\mathrm{Fe}^{0}\right]\left(\mathrm{g} \mathrm{L}^{-1}\right) \leq 45$. The following systems where investigated: $\mathrm{Fe}^{0}, \mathrm{MnO}_{2}$, sand, $\mathrm{Fe}^{0} / \mathrm{MnO}_{2}, \mathrm{Fe}^{0}$ / sand, and $\mathrm{Fe}^{0} / \mathrm{MnO}_{2}$ / sand. Results demonstrated that $\mathrm{MB}$ discoloration is influenced by the diffusive transport of $\mathrm{MB}$ from the solution to the aggregates at the bottom of the test-tubes. Results confirm the complexity of the $\mathrm{Fe}^{0} / \mathrm{MnO}_{2} /$ sand system, while establishing that both $\mathrm{MnO}_{2}$ and sand improve the efficiency of $\mathrm{Fe}^{0} / \mathrm{H}_{2} \mathrm{O}$ systems in the long-term. The mechanisms of water decontamination by amending $\mathrm{Fe}^{0}$-based systems with $\mathrm{MnO}_{2}$ is demonstrated by the $\mathrm{MB}$ method.
\end{abstract}

Keywords: manganese oxides; MB method; reactivity materials; water treatment; zero-valent iron

\section{Introduction}

The use of metallic iron $\left(\mathrm{Fe}^{0}\right)$ for environmental remediation and water treatment has boomed during the past three decades [1-3]. Under environmental conditions, $\mathrm{Fe}^{0}$ is spontaneously oxidized to $\mathrm{Fe}^{\mathrm{II}}$ and $\mathrm{Fe}^{\mathrm{III}}$ oxides/hydroxides (iron corrosion products-FeCPs) which remove contaminants from an aqueous solution by adsorption and co-precipitation [4-7]. An inherent problem of $\mathrm{Fe}^{0}$ is that its corrosion rate decreases with increasing service life [8]. This property has been termed as reactivity loss in the $\mathrm{Fe}^{0}$ literature. Since the end of the 1990s, efficient tools have been sought to address "reactivity loss" or improve the corrosion rate. Tested approaches include [1,3]: increasing the specific surface area including using nano- $\mathrm{Fe}^{0}$, alloying $\mathrm{Fe}^{0}$ with more noble metals (e.g., $\mathrm{Fe}^{0} / \mathrm{Pd}^{0}$ ), adding oxidizing solutions (e.g., $\mathrm{H}_{2} \mathrm{O}_{2}, \mathrm{O}_{3}$ ), and admixing with other aggregates (e.g., gravel, $\mathrm{MnO}_{2}$, pyrite, sand). Except for $\mathrm{MnO}_{2}$ addition, it is very difficult to maintain the enhanced $\mathrm{Fe}^{0}$ oxidation effect for a long time. There are three main reasons: (i) added oxidizers are unstable solutions (e.g., $\mathrm{H}_{2} \mathrm{O}_{2}$ ), (ii) oxidation enhancers are in limited quantity (e.g., bimetallic coating), and (iii) the enhancing capacity of the aggregate is limited (e.g., gravel, sand). In contrary, the 
addition of $\mathrm{MnO}_{2}$ potentially creates a reactive $\mathrm{Fe}$ and $\mathrm{Mn}$ oxides mixture, for which long term reactivity is acknowledged but yet to be investigated [9,10].

$\mathrm{Fe}^{0} / \mathrm{MnO}_{2}$ systems have been extensively investigated during the past two decades and include: (i) $\mathrm{Fe}^{0} / \mathrm{MnO}_{2}$ composites [11,12] and (ii) $\mathrm{Fe}^{0} / \mathrm{MnO}_{2}$ mixtures [7,13]. There is an agreement on the $\mathrm{MnO}_{2}$ enhancing decontamination effects in $\mathrm{Fe}^{0} / \mathrm{H}_{2} \mathrm{O}$ system, but reported disagreement on the actual operating mode of this system. Theoretically, $\mathrm{MnO}_{2}$ can influence contaminant removal via adsorption, catalysis, and redox activities [14]. $\mathrm{MnO}_{2}$ participates in oxidation of selected contaminants (e.g., aromatic amines, antibiotics). It can also function in a galvanic cell with iron to promote electron transfer on the surface of iron to alleviate $\mathrm{Fe}^{0}$ passivation. The following three examples illustrate discrepancy in reports (i) Liang et al. [12] reported that there was no galvanic cells between $\mathrm{Fe}^{0}$ and $\mathrm{MnO}_{2}$ in $\mathrm{Fe}^{0} / \mathrm{MnO}_{2}$ composites for As removal. Rather, there is formation of a Fe/Mn binary oxides layer on the $\mathrm{Fe}^{0}$ surface resulting in intensive corrosion. In other words, Liang et al. [12] argued that binary Fe/Mn oxides avoid or suppress the formation of crystalline iron (hydr)oxides. (ii) Gheju and Balcu [7] argued that the favorable synergistic effect of $\mathrm{Fe}^{0} / \mathrm{MnO}_{2}$ mixtures results from the capacity of $\mathrm{MnO}_{2}$ to accelerate $\mathrm{Fe}^{0}$ oxidative dissolution. Thereby, supplementary amounts of secondary adsorbents and reductants are generated for $\mathrm{Cr}^{\mathrm{VI}}$ removal and reduction. (iii) Dong et al. [14] enhanced electron transfer "on the surface of $\mathrm{Fe}^{0}$ with the presence of $\mathrm{MnO}_{2}$ " in the process of tetracycline removal, yielding a more sustainable $\mathrm{Fe}^{0} / \mathrm{H}_{2} \mathrm{O}$ system to lengthen the lives of the $\mathrm{Fe}^{0}$ filtration system. There is an urgent need to clarify the real operating mode of the $\mathrm{Fe}^{0} / \mathrm{MnO}_{2}$ system.

This study seeks to clarify the operating mode of $\mathrm{Fe}^{0} / \mathrm{MnO}_{2}$ systems using the methylene blue discoloration method (MB method). The MB method entails characterizing MB discoloration in $\mathrm{Fe}^{0}$ /sand systems $[15,16]$. The $\mathrm{Fe}^{0} / \mathrm{MnO}_{2} /$ sand system is characterized for MB discoloration for 7 days. A commercial $\mathrm{Fe}^{0}$ specimen and a natural $\mathrm{MnO}_{2}$ mineral are used. Three single $\left(\mathrm{Fe}^{0}, \mathrm{MnO}_{2}\right.$, sand), two binary $\left(\mathrm{Fe}^{0} / \mathrm{MnO}_{2}\right.$ and $\mathrm{Fe}^{0} /$ sand $)$ and one ternary $\left(\mathrm{Fe}^{0} / \mathrm{MnO}_{2} /\right.$ sand) systems are investigated and the results are comparatively discussed.

\section{The $\mathrm{Fe}^{0} / \mathrm{MnO}_{2}$ System}

Aqueous contaminant removal in the presence of $\mathrm{Fe}^{0}$ primary depends on the chemical thermodynamics of two redox systems: $\mathrm{Fe}^{\mathrm{II}} / \mathrm{Fe}^{0}\left(\mathrm{E}^{0}=-0.44 \mathrm{~V}\right)$ and $\mathrm{H}^{+} / \mathrm{H}_{2} \mathrm{O}\left(\mathrm{E}^{0}=0.00 \mathrm{~V}\right)$. Both aqueous solution behavior and redox thermodynamics should be considered. In addition, the eventual redox properties of contaminants (e.g., As, $\mathrm{Cr}, \mathrm{MB}$ ) and additives (e.g., $\mathrm{Fe}_{3} \mathrm{O}_{4}, \mathrm{FeS}_{2}, \mathrm{MnO}_{2}$ ) are to be equally considered. Table 1 summarizes the half-redox reactions relevant for the discussion in this paper and their electrode potential. As a rule, $\mathrm{Fe}^{0}$ can be oxidized by the reducing agent of all couples with $\mathrm{E}^{0}>-0.44 \mathrm{~V}$.

Table 1. Electrode potentials of redox reactions relevant for the discussion in this study (modified after Reference [17]). $\mathrm{MB}^{+}$is the cationic methylene blue (MB), and LMB is its colorless reduced form.

\begin{tabular}{ccc}
\hline Reaction & $\begin{array}{c}\mathbf{E}^{\mathbf{0}} \\
\text { (V) }\end{array}$ & Number \\
\hline $\mathrm{Fe}^{2+}+2 \mathrm{e}^{-} \Leftrightarrow \mathrm{Fe}^{0}$ & -0.44 & $(1)$ \\
\hline $2 \mathrm{H}^{+}+2 \mathrm{e}^{-} \Leftrightarrow \mathrm{H}_{2}$ & 0.00 & $(2)$ \\
\hline $\mathrm{MB}^{+}+2 \mathrm{e}^{-}+\mathrm{H}^{+} \Leftrightarrow \mathrm{LMB}$ & 0.01 & $(3)$ \\
\hline $\mathrm{Fe}^{3+}+\mathrm{e}^{-} \Leftrightarrow \mathrm{Fe}^{2+}$ & 0.77 & $(4)$ \\
\hline $\mathrm{O}_{2}+2 \mathrm{H}_{2} \mathrm{O}+4 \mathrm{e}^{-} \Leftrightarrow 4 \mathrm{OH}^{-}$ & 0.81 & $(5)$ \\
\hline $\mathrm{MnO}_{2}+4 \mathrm{H}^{+}+2 \mathrm{e}^{-} \Leftrightarrow \mathrm{Mn}^{2+}+2 \mathrm{H}_{2} \mathrm{O}$ & 1.23 & $(6)$ \\
\hline
\end{tabular}

The five theoretically possible redox reactions $\left(\mathrm{E}^{0}>-0.44 \mathrm{~V}\right)$ are $\mathrm{Fe}^{0}$ oxidation by: (i) water $\left(\mathrm{H}^{+}\right)$, (ii) methylene blue $\left(\mathrm{MB}^{+}\right)$, (iii) ferric iron $\left(\mathrm{Fe}^{3+}\right)$, (iv) dissolved oxygen $\left(\mathrm{O}_{2}\right)$, and (v) manganese dioxide $\left(\mathrm{MnO}_{2}\right)$. However, it has been clearly established that, at $\mathrm{pH}>4.5$ only water oxidized $\mathrm{Fe}^{0}[18,19]$. In other words, $\mathrm{Fe}^{0}$ cannot be the anodic reaction 
simultaneous to the reduction of $\mathrm{MB}^{+}, \mathrm{O}_{2}$ and $\mathrm{MnO}_{2}$. Clearly, wherever these species have been reduced in a $\mathrm{Fe}^{0} / \mathrm{H}_{2} \mathrm{O}$ system, electron donors were primary $\left(\mathrm{Fe}^{\mathrm{II}}, \mathrm{H}_{2}\right)$ or secondary $\left(\mathrm{Fe}_{3} \mathrm{O}_{4}\right.$, green rust) iron corrosion products. This knowledge is century old [2,18]. The major reason why electrons from $\mathrm{Fe}^{0}$ are not available to dissolved species is that the $\mathrm{Fe}^{0}$ surface is always covered by an oxide scale which acts as a diffusion barrier for dissolved species, and an electronic barrier for electrons. Concerning ferric ions (Table 1 (4)), it is considered that $\mathrm{Fe}^{3+}$ ions are generated in the vicinity of $\mathrm{Fe}^{0}$ and may exchange electrons with the metal body. Clearly, the only two possible electrochemical reactions in a $\mathrm{Fe}^{0} / \mathrm{H}_{2} \mathrm{O}$ system are (Equations (1) and (2)):

$$
\begin{gathered}
\mathrm{Fe}^{0}+2 \mathrm{H}^{+} \Rightarrow \mathrm{Fe}^{2+}+\mathrm{H}_{2} \\
\mathrm{Fe}^{0}+2 \mathrm{Fe}^{3+} \Rightarrow 3 \mathrm{Fe}^{2+}
\end{gathered}
$$

There are many possible reaction combinations emanating from Table 1 . The discussion is limited on the fate of $\mathrm{MB}^{+}, \mathrm{MnO}_{2}$ and $\mathrm{O}_{2}$, which are reactants in this study. The survey of the $\mathrm{E}^{0}$ values reveals two key issues: (i) $\mathrm{Fe}^{3+}$ and $\mathrm{MnO}_{2}$ oxidize $\mathrm{LMB}$ to $\mathrm{MB}^{+}$, and (ii) $\mathrm{O}_{2}$ and $\mathrm{MnO}_{2}$ oxidize $\mathrm{Fe}^{2+}$. In other words, $\mathrm{MB}$ discoloration by a redox process is not possible in the $\mathrm{Fe}^{0} / \mathrm{H}_{2} \mathrm{O}$ system, while the production of $\mathrm{Fe}^{\mathrm{III}}$ species might be quantitative. $\mathrm{Fe}^{\mathrm{III}}$ oxides are contaminant scavengers and in this study discoloring agents for MB [16]. Clearly, $\mathrm{Fe}^{2+}$ from iron corrosion (Table 1 (1)) is initially used to reduce $\mathrm{MnO}_{2}$ (Equation (3)). Once the oxidative capacity of $\mathrm{MnO}_{2}$ is exhausted, "excess" Fe ${ }^{\mathrm{III}}$ oxides are generated for $\mathrm{MB}$ quantitative discoloration by adsorption and co-precipitation.

$$
2 \mathrm{Fe}^{2+}+\mathrm{MnO}_{2}+2 \mathrm{H}_{2} \mathrm{O} \Rightarrow \mathrm{Mn}^{2+}+2 \mathrm{FeOOH}+2 \mathrm{H}^{+}
$$

To summarize, the chemistry of the $\mathrm{Fe}^{0} / \mathrm{MnO}_{2}$ system shows two important features: (i) $\mathrm{Fe}^{0}$ cannot exchange electrons with any dissolved species, and (ii) $\mathrm{MnO}_{2}$ cannot form a galvanic cell with $\mathrm{Fe}^{0}$. The remaining theoretical possibilities are: (i) $\mathrm{MnO}_{2}$ influences contaminant removal via adsorption, catalysis, co-precipitation and redox activities (Assertion 1), (ii) $\mathrm{MnO}_{2}$ participates in the oxidation of selected contaminants (Assertion 2), and (iii) $\mathrm{MnO}_{2}$ disturbs the formation of oxide scales in the vicinity of $\mathrm{Fe}^{0}$ (Assertion 3). Assertion 3 is obvious and universally valid as even external $\mathrm{Fe}^{2+}$ disturbs the formation of oxide scale [6,17]. The remaining task is to check the validity of Assertion 1 and Assertion 2 on a case specific basis. Herein, the discussion is eased by the evidence that MB has not adsorptive nor reductive affinities with the species in presence. In other words, MB discoloration results from co-precipitation with excess FeCPs. Adding sand to the system is inherent to the MB method [16], wherein the discoloration of MB by sand is inhibited as it is progressively coated by in-situ generated FeCPs. The validity of Assertion 1 and Assertion 2 will be tested for the $\mathrm{Fe}^{0} / \mathrm{MnO}_{2} / \mathrm{MB}$ system.

\section{Materials and Methods}

This experimental section is adapted from Xiao et al. [20] using the same experimental design but quiescent experiments $(0 \mathrm{rpm})$ and pyrite $\left(\mathrm{FeS}_{2}\right)$ as an additive.

\subsection{Solutions}

The used methylene blue (MB-Basic Blue 9 from Merck) was of analytical grade. The working solution was $10.0 \mathrm{mg} \mathrm{L}^{-1}$ prepared by diluting a $1000 \mathrm{mg} \mathrm{L}^{-1}$ stock solution. The stock solution was prepared by dissolving accurately weighted MB in tap water. The use of tap water rather than deionized water was motivated by the fact that tap water is closer to natural water in its chemical composition. The $\mathrm{MB}$ molecular formula is $\mathrm{C}_{16} \mathrm{H}_{18} \mathrm{~N}_{3} \mathrm{SCl}$ corresponding to a molecular weight of $319.85 \mathrm{~g}$. MB was chosen in this study because of its well-known strong adsorption onto solids [20]. 


\subsection{Solid Materials}

\subsubsection{Metallic Iron $\left(\mathrm{Fe}^{0}\right)$}

The used $\mathrm{Fe}^{0}$ material was purchased from iPutech (Rheinfelden, Germany). The material is available as filings with a particle size between 0.3 and $2.0 \mathrm{~mm}$. Its elemental composition as specified by the supplier was: C: $3.52 \%$; Si: $2.12 \%$; Mn: $0.93 \%$; Cr: $0.66 \%$ while the balance was Fe. The material was used without any further pre-treatment. $\mathrm{Fe}^{0}$ was proven as a powerful discoloration agent for MB given that discoloration agents in the form of FeCPs are progressively generated in situ [20].

\subsubsection{Manganese Dioxide $\left(\mathrm{MnO}_{2}\right)$}

The tested natural $\mathrm{MnO}_{2}$-bearing minerals was Manganit from Ilfeld/Harz, Thüringen (Germany). The mineral was crushed and fractionated by sieving. The fraction $0.5-1.0 \mathrm{~mm}$ was used without any further pre-treatment. No chemical, mineralogical nor structural characterizations were performed. $\mathrm{MnO}_{2}$ is a reactive mineral $[21,22]$ and is used to delay the availability of "free" iron corrosion products (FeCPs) in the system. This results in a delay of quantitative MB discoloration [16].

\subsubsection{Sand}

The used sand was a commercial material for aviculture ("Papagaiensand" from RUT-Lehrte/Germany). The sand was used as received without any further pre-treatment. The particle size was between 2.0 and $4.0 \mathrm{~mm}$. Sand was used as an adsorbent because of its worldwide availability and its use as admixing agent in $\mathrm{Fe}^{0}$ barriers [23,24]. The adsorption capacity of sand for MB has been systematically documented as early as in 1955 by Mitchell et al. [25].

\section{3. $M B$ Discoloration}

Shaken batch experiments at $75 \mathrm{rpm}$ were conducted in assay tubes for an experimental duration of $7 \mathrm{~d}$. The batches consisted of 0.0 or $1.0 \mathrm{~g}$ of sand, 0.0 to $0.1 \mathrm{~g}$ to $\mathrm{Fe}^{0}, 0.0$ or $0.05 \mathrm{~g}$ of $\mathrm{MnO}_{2}$ and mixtures thereof in $22.0 \mathrm{~mL}$ of a $10.0 \mathrm{mg} \mathrm{L}^{-1} \mathrm{MB}$ solution. The six investigated systems were: (i) $\mathrm{Fe}^{0}$ alone, (ii) sand alone, (iii) $\mathrm{MnO}_{2}$ alone, (iv) $\mathrm{Fe}^{0} /$ sand, (v) $\mathrm{Fe}^{0} / \mathrm{MnO}_{2}$ and (vi) $\mathrm{Fe}^{0} /$ sand $/ \mathrm{MnO}_{2}$. The efficiency of individual systems at discoloring $\mathrm{MB}$ was characterized at laboratory temperature (about $22^{\circ} \mathrm{C}$ ). Initial $\mathrm{pH}$ was about 8.2. After equilibration, up to $3.0 \mathrm{~mL}$ of the supernatant solutions were carefully retrieved (no filtration) for MB measurements (no dilution). Each experiment was performed in triplicate, and averaged values are presented. Table 2 summarizes the aggregate content of the $6 \mathrm{Fe}^{0} / \mathrm{MnO}_{2} /$ sand systems investigated herein. The operational reference (blank experiment) is also added. Note that the pure $\mathrm{Fe}^{0}$ system $\left(\mathrm{Fe}^{0}\right.$ alone) is regarded as a ' $\mathrm{Fe}^{0} / \mathrm{MnO}_{2} /$ sand system', without $\mathrm{MnO}_{2}$ nor sand.

Table 2. Overview of the six (6) investigated systems. The material loadings correspond to Figure 1.

\begin{tabular}{cccccc}
\hline System & $\begin{array}{c}\mathrm{Fe}^{\mathbf{0}} \\
\left(\mathbf{g ~ L}^{-\mathbf{1}}\right)\end{array}$ & $\begin{array}{c}\text { Sand } \\
\left(\mathbf{g ~ L}^{-\mathbf{1}}\right)\end{array}$ & $\begin{array}{c}\mathbf{M n O}_{\mathbf{2}} \\
\left(\mathbf{g ~ L}^{-\mathbf{1}}\right)\end{array}$ & Materials & Comments \\
\hline Reference & 0.0 & 0.0 & 0.0 & None & Blank experiment \\
\hline System 1 & 4.5 & 0.0 & 0.0 & $\mathrm{Fe}^{0}$ alone & Blank for $\mathrm{Fe}^{0}$ \\
\hline System 2 & 0.0 & 45.0 & 0.0 & Sand alone & Blank for sand \\
\hline System 3 & 0.0 & 0.0 & 2.3 & $\mathrm{MnO}_{2}$ alone & Blank for $\mathrm{MnO}_{2}$ \\
\hline System 4 & 4.5 & 45.0 & 0.0 & $\mathrm{Fe}^{0} /$ sand & Reference system \\
\hline System 5 & 4.5 & 0.0 & 4.5 & $\mathrm{Fe}^{0} / \mathrm{MnO}_{2}$ & Reference system \\
\hline System 6 & 4.5 to 45 & 45.0 & 4.5 & $\mathrm{Fe}^{0} /$ sand $/ \mathrm{MnO}_{2}$ & $\mathrm{Fe}^{0}$ loading as variable \\
\hline
\end{tabular}




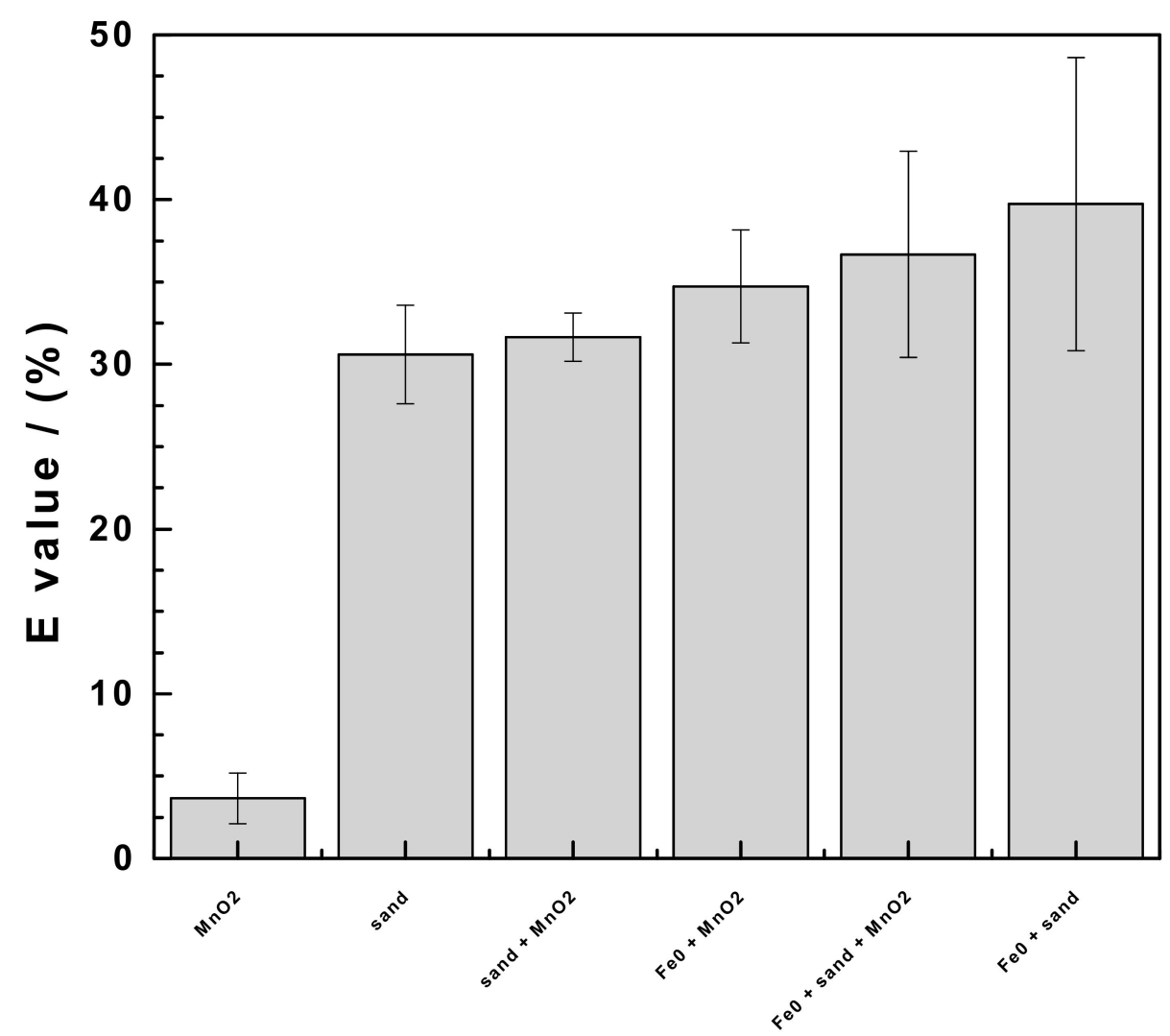

Figure 1. Comparison of the efficiency of tested materials for methylene blue (MB) discoloration for 7 days. Experimental conditions: $\left[\mathrm{Fe}^{0}\right]=0$ to $45 \mathrm{~g} \mathrm{~L}-1$; [sand] $=45 \mathrm{~g} \mathrm{~L}-1$; and $\left[\mathrm{MnO}_{2}\right]=2.3 \mathrm{~g} \mathrm{~L}-1$, shaken intensity: $75 \mathrm{rpm}$.

\subsection{Analytical Methods}

Iron and $\mathrm{MB}$ aqueous concentrations were determined by a Cary $50 \mathrm{UV}$-Vis spectrophotometer (Varian). The working wavelengths for $\mathrm{MB}$ and iron were 664.5 and $510.0 \mathrm{~nm}$, respectively. Cuvettes with a $1.0 \mathrm{~cm}$ light path were used. The spectrophotometer was calibrated for Fe and $\mathrm{MB}$ concentrations $\leq 10.0 \mathrm{mg} \mathrm{L}^{-1}$. The $\mathrm{pH}$ value was measured by combined glass electrodes (WTW Co., Oberbayern, Germany).

\subsection{Expression of $M B$ Discoloration Results (E Value)}

In order to characterize the magnitude of the tested systems for MB discoloration, the discoloration efficiency (E) was calculated (Equation (4)). After the determination of the residual $\mathrm{MB}$ concentration $(\mathrm{C})$, the corresponding percent $\mathrm{MB}$ discoloration (E value) was calculated as:

$$
\mathrm{E}=\left[1-\left(\mathrm{C} / \mathrm{C}_{0}\right)\right] \times 100 \%
$$

Where, $C_{0}$ is the initial aqueous $\mathrm{MB}$ concentration (ideally $10.0 \mathrm{mg} \mathrm{L}^{-1}$ ), while $C_{\text {gives }}$ the $\mathrm{MB}$ concentration after the experiment. The operational initial concentration $\left(\mathrm{C}_{0}\right)$ for each case was acquired from a triplicate control experiment without additive material (so-called blank). This procedure was to account for experimental errors during dilution of the stock solution, $\mathrm{MB}$ adsorption onto the walls of the reaction vessels, and all other possible side reactions during the experiments.

\section{Results and Discussion}

\subsection{Evidence for the Complexity of the $\mathrm{Fe}^{0} / \mathrm{MnO}_{2}$ System}

Figure 1 summarizes the extent of $\mathrm{MB}$ discoloration in the six investigated systems. It is seen that the pure $\mathrm{MnO}_{2}$ system does not exhibit any significant $\mathrm{MB}$ discoloration 
while the remaining systems exhibited $\mathrm{E}$ values varying from 30 to $40 \%$. All these systems have in common the presence of sand $\left(45.0 \mathrm{~g} \mathrm{~L}^{-1}\right)$ and those containing $\mathrm{Fe}^{0}$, additionally contains $4.5 \mathrm{~g} \mathrm{~L}^{-1}$ of this reactive material. The evidence that adding $4.5 \mathrm{~g} \mathrm{~L}^{-1}$ of $\mathrm{Fe}^{0}$ and $2.3 \mathrm{~g} \mathrm{~L}^{-1}$ of $\mathrm{MnO}_{2}$ to $45.0 \mathrm{~g} \mathrm{~L}^{-1}$ sand does not significantly improve the extent of $\mathrm{MB}$ discoloration can be regarded as intriguing. Previous reports using quiescent batch experiments even reported on an initial decrease of $\mathrm{E}$ values in $\mathrm{Fe}^{0} / \mathrm{H}_{2} \mathrm{O}$ systems due to the presence of both $\mathrm{MnO}_{2}$ and sand [16]. Clearly, while increasing the available surface area (different materials), MB discoloration is not initially improved. This can be justified by one or both of the following hypotheses: (i) chemical reactions occurring in the system hinder MB discoloration by adsorption onto sand (Hypothesis 1), and (ii) there are chemical interactions between available aggregates (e.g., $\mathrm{Fe}^{0}$ and $\mathrm{MnO}_{2}$ ) avoiding or delaying $\mathrm{MB}$ discoloration (Hypothesis 2). Hypothesis 1 corresponds to the historical observation by Mitchell et al. [25] that clean sand is a better adsorbent for MB that iron oxide-coated sand. This idea is also the cornerstone of the MB method and the reason why sand was added in the present study. Hypothesis 2 considers the reactive nature of $\mathrm{MnO}_{2}[21,22]$ and encompasses the fact that by using $\mathrm{Fe}^{2+}$ for its reductive dissolution (Equation (3)), $\mathrm{MnO}_{2}$ is delaying the availability of 'free' FeCPs for MB discoloration by co-precipitation [26].

Hypothesis 1: Chemical reactions occurring in the system hinder MB discoloration by adsorption onto sand.

Hypothesis 2: There are chemical interactions between available aggregates (e.g., $\mathrm{Fe}^{0}$ and $\mathrm{MnO}_{2}$ ) avoiding or delaying $M B$ discolor-ation.

A closer look at Figure 1 reveals the following increasing order of $\mathrm{E}$ values: $\mathrm{MnO}_{2}$ $(3 \%)<$ sand $(30 \%)<\mathrm{MnO}_{2} /$ sand $(31 \%)<\mathrm{Fe}^{0} / \mathrm{MnO}_{2}(34 \%)<\mathrm{Fe}^{0} / \mathrm{MnO}_{2} /$ sand $(36 \%)$ $<\mathrm{Fe}^{0} /$ sand $(40 \%)$. Considering the standard deviations (Figure 1) it is clear that there was no significant difference between the performance of the three $\mathrm{Fe}^{0}$-bearing systems: $\mathrm{Fe}^{0} / \mathrm{MnO}_{2}(34 \pm 4 \%)<\mathrm{Fe}^{0} / \mathrm{MnO}_{2} /$ sand $(36 \pm 7 \%)<\mathrm{Fe}^{0} /$ sand $(40 \pm 9 \%)$. Considering the absolute values, the ternary system $\left(\mathrm{Fe}^{0} / \mathrm{MnO}_{2} /\right.$ sand) performed less than the binary system with sand $\left(\mathrm{Fe}^{0} /\right.$ sand). For binary systems, $\mathrm{Fe}^{0} / \mathrm{MnO}_{2}$ exhibited the lowest extent of $\mathrm{MB}$ discoloration. These observations collectively validate Hypothesis 2: $\mathrm{MnO}_{2}$ reductive dissolution initially decreases the number of active sites for $\mathrm{MB}$ discoloration. This is because $\mathrm{Fe}^{2+}$ oxidation (Equation (3)) occurs at the $\mathrm{MnO}_{2}$ surface and resulting $\mathrm{Fe}{ }^{\mathrm{III}}$ oxides coat the $\mathrm{MnO}_{2}$ surface and is thus not available for the co-precipitation of the cationic dye (MB).

The remainder of the presentation discusses changes in the ternary $\mathrm{Fe}^{0} / \mathrm{MnO}_{2} /$ sand system as the $\mathrm{Fe}^{0}$ loading varies from 0 to $45 \mathrm{~g} \mathrm{~L}^{-1}$ while the sand loading is $45 \mathrm{~g} \mathrm{~L}^{-1}$ and the $\mathrm{MnO}_{2}$ loading $2.3 \mathrm{~g} \mathrm{~L}^{-1}$.

\section{2. $M B$ Discoloration}

Figure 2 summarizes changes of the $\mathrm{E}$ values in the systems $\mathrm{Fe}^{0} / \mathrm{MnO}_{2}, \mathrm{Fe}^{0} /$ sand, and $\mathrm{Fe}^{0} / \mathrm{MnO}_{2} /$ sand as the $\mathrm{Fe}^{0}$ loading varied from 0 to $45 \mathrm{~g} \mathrm{~L}^{-1}$. It is seen that at $\left[\mathrm{Fe}^{0}\right]=0 \mathrm{~g} \mathrm{~L}^{-1}$, the two sand-bearing systems exhibited an $\mathrm{E}$ value close to $30 \%$. This corresponds to the results reported in Figure 1 and is in tune with the observation of Mitchell et al. [25], that sand is an excellent adsorbent for MB [15,16]. It is also seen that the $\mathrm{E}$ value monotonously increases with increasing $\mathrm{Fe}^{0}$ loadings reaching a maximum value of about $52 \%$ for the $\mathrm{Fe}^{0} /$ sand system and $64 \%$ for the ternary system respectively. The observation that the ternary system performed better than the binary may be misunderstood as contrary to the reports in Section 1 (Figure 1). However, data in Figure 1 corresponds to $\left[\mathrm{Fe}^{0}\right]=4.5 \mathrm{~g} \mathrm{~L}^{-1}$. Figure 2 clearly shows that for this $\mathrm{Fe}^{0}$ loading, $\mathrm{Fe}^{0}$ / sand performs better than $\mathrm{Fe}^{0} / \mathrm{MnO}_{2} /$ sand. The better performance of the ternary system relative to $\mathrm{Fe}^{0}$ /sand for $\left[\mathrm{Fe}^{0}\right]>10 \mathrm{~g} \mathrm{~L}^{-1}$, is attributed to the action of $\mathrm{MnO}_{2}$ in reinforcing $\mathrm{Fe}^{0}$ corrosion and producing "excess" FeCPs for MB co-precipitation. This operating mode is illustrated the 
best in the binary $\mathrm{Fe}^{0} / \mathrm{MnO}_{2}$ system which performed lower that the sand-bearing systems for $\left[\mathrm{Fe}^{0}\right]<10 \mathrm{~g} \mathrm{~L}^{-1}$, and far higher for $\left[\mathrm{Fe}^{0}\right]>10 \mathrm{~g} \mathrm{~L}^{-1}$, reaching $70 \%$ at $\left[\mathrm{Fe}^{0}\right]=45 \mathrm{~g} \mathrm{~L}^{-1}$.

$\mathrm{The} \mathrm{Fe}^{0} / \mathrm{MnO}_{2}$ system shows a diphasic pattern in the process of $\mathrm{MB}$ discoloration. The initial discoloration (up to $\left[\mathrm{Fe}^{0}\right]=12 \mathrm{~g} \mathrm{~L}^{-1}$ ) is very rapid, followed by slower discoloration for higher $\left[\mathrm{Fe}^{0}\right]$ values. It can be considered that for $\left[\mathrm{Fe}^{0}\right]<12 \mathrm{~g} \mathrm{~L}^{-1}$, the $\mathrm{Fe}^{0} / \mathrm{MnO}_{2}$ ratio is optimal to avoid intra-particle diffusion such that "excess" FeCPs is immediately available for $\mathrm{MB}$ co-precipitation. For $\left[\mathrm{Fe}^{0}\right]>12 \mathrm{~g} \mathrm{~L}^{-1}, \mathrm{MB}$ must diffuse through a thicker layer of $\mathrm{Fe}^{0}$ particles at the bottom of the test-tubes. Remember that in the presence of sand, the diffusion paths are larger and explain why, for higher $\mathrm{Fe}^{0}$ loadings, the ternary system performed less than the $\mathrm{Fe}^{0} / \mathrm{MnO}_{2}$ system, despite initial rapid adsorption onto sand. In other words, after the complete coverage of sand by FeCPs, MB discoloration solely results from co-precipitation with free $\mathrm{FeCPs}$. These free FeCPs are less available in the ternary system compared to the binary $\mathrm{Fe}^{0} / \mathrm{MnO}_{2}$ system.

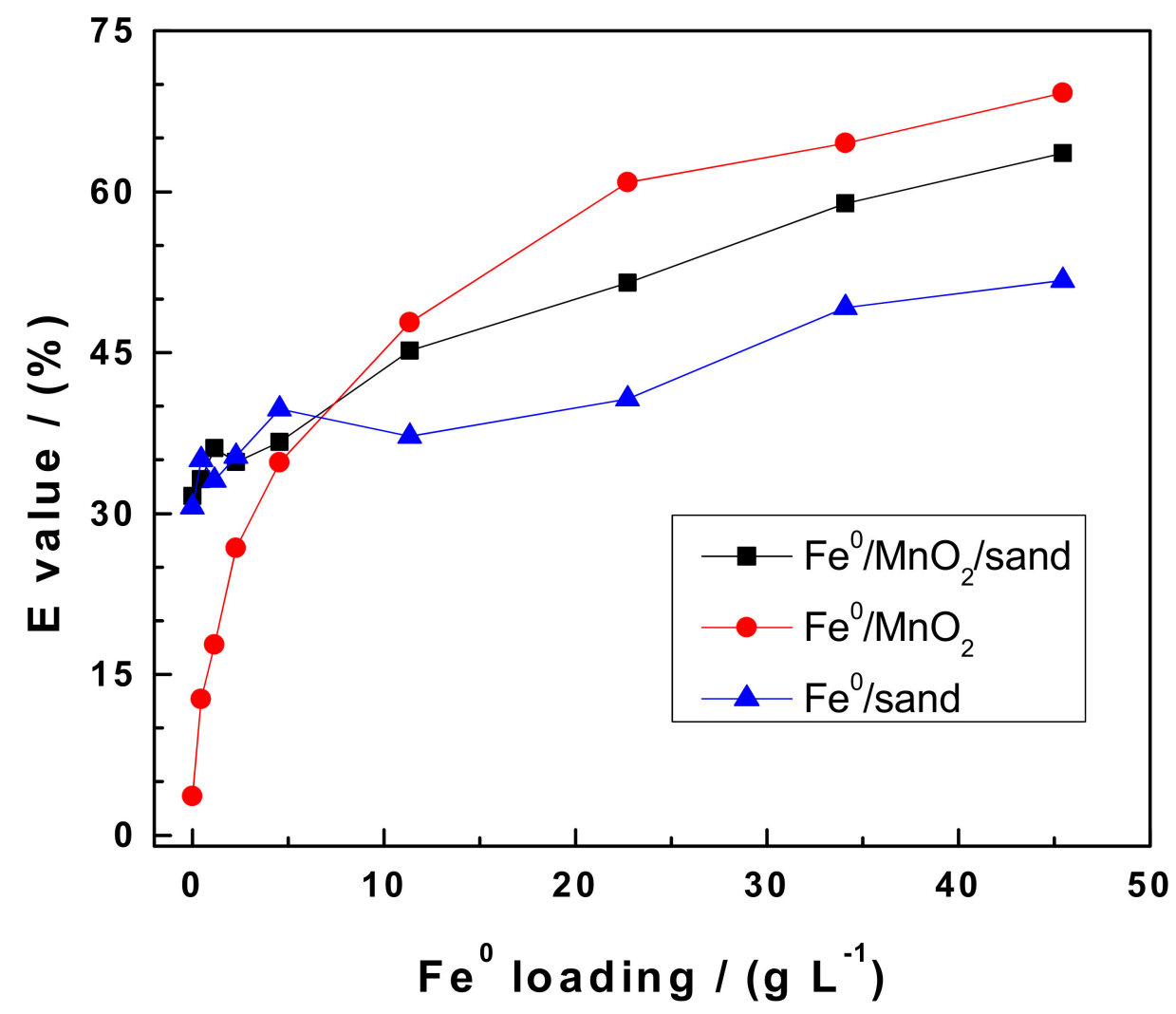

Figure 2. Methylene blue discoloration in $\mathrm{Fe}^{0} /$ sand $/ \mathrm{MnO}_{2}$ systems as impacted by the addition of various $\mathrm{Fe}^{0}$ loading for 7 days. Experimental conditions: [ $\left.\mathrm{Fe}^{0}\right]=2.3$ to $45 \mathrm{~g} \mathrm{~L}-1$; [sand] $=45 \mathrm{~g} \mathrm{~L}-1$; and $\left[\mathrm{MnO}_{2}\right]=2.3 \mathrm{~g} \mathrm{~L}-1$, shaken intensity: $75 \mathrm{rpm}$. The lines are not fitting functions, they simply connect points to facilitate visualization.

\section{3. $\mathrm{pH}$ Value}

Figure 3 summarizes changes of the $\mathrm{pH}$ values in the systems $\mathrm{Fe}^{0} / \mathrm{MnO}_{2}, \mathrm{Fe}^{0} /$ sand, and $\mathrm{Fe}^{0} / \mathrm{MnO}_{2} /$ sand as the $\mathrm{Fe}^{0}$ loading varied from 0 to $45 \mathrm{~g} \mathrm{~L}^{-1}\left(\mathrm{pH}_{0}=8.2\right)$. It is seen that for $\left[\mathrm{Fe}^{0}\right]<10 \mathrm{~g} \mathrm{~L}^{-1}$, the three systems exhibited very different behaviors; the $\mathrm{pH}$ value (i) first decreased to a minimum of 7.8 for $\left[\mathrm{Fe}^{0}\right]=2.3 \mathrm{~g} \mathrm{~L}^{-1}$ in the $\mathrm{Fe}^{0} / \mathrm{MnO}_{2} /$ sand system, (ii) is constant to 8.1 in the $\mathrm{Fe}^{0}$ /sand system, and (iii) monotonously increased in the $\mathrm{Fe}^{0} / \mathrm{MnO}_{2}$ system. The two processes determining the final $\mathrm{pH}$ value in each systems are: (i) iron corrosion consuming protons (Equation (1)), and $\mathrm{MnO}_{2}$ reductive dissolution releasing protons (Equation (3)). Accordingly, in the $\mathrm{Fe}^{0}$ /sand system, only iron corrosion fixes the $\mathrm{pH}$ and the constant value for $\left[\mathrm{Fe}^{0}\right]<11 \mathrm{~g} \mathrm{~L}^{-1}$ corresponds to $\mathrm{H}^{+}$adsorption onto 
the surface of sand. The $\mathrm{pH}$ starts to increase only after the ion exchange capacity of sand for $\mathrm{H}^{+}$is exhausted.

Concerning the $\mathrm{Fe}^{0} / \mathrm{MnO}_{2}$ system, there was a slight $\mathrm{pH}$ decrease for $\left[\mathrm{Fe}^{0}\right]=0.5$ and $1.1 \mathrm{~g} \mathrm{~L}^{-1}$ but from $\left[\mathrm{Fe}^{0}\right]=2.3 \mathrm{~g} \mathrm{~L}^{-1}$ onwards, there was an increase of the $\mathrm{pH}$ value. This means that under the experimental conditions (e.g., used mass loading and shaken at $75 \mathrm{rpm}$ for 7 days), $\mathrm{MnO}_{2}$ reductive dissolution fixed the final $\mathrm{pH}$ value only for $\left[\mathrm{Fe}^{0}\right]<2.3 \mathrm{~g} \mathrm{~L}^{-1}$. For higher $\mathrm{Fe}^{0}$ loadings, the $\mathrm{pH}$ is fixed by iron corrosion and the final $\mathrm{pH}$ values determined by the extent to which free protons are released to the solution above the mixture of aggregates (e.g., $\mathrm{Fe}^{0}, \mathrm{MnO}_{2}$ and sand). For this reason, the $\mathrm{Fe}^{0} / \mathrm{MnO}_{2}$ (without sand) exhibited larger final $\mathrm{pH}$ values than the $\mathrm{Fe}^{0} / \mathrm{MnO}_{2}$ / sand in which protons are fixed at the negatively charged sand surface.

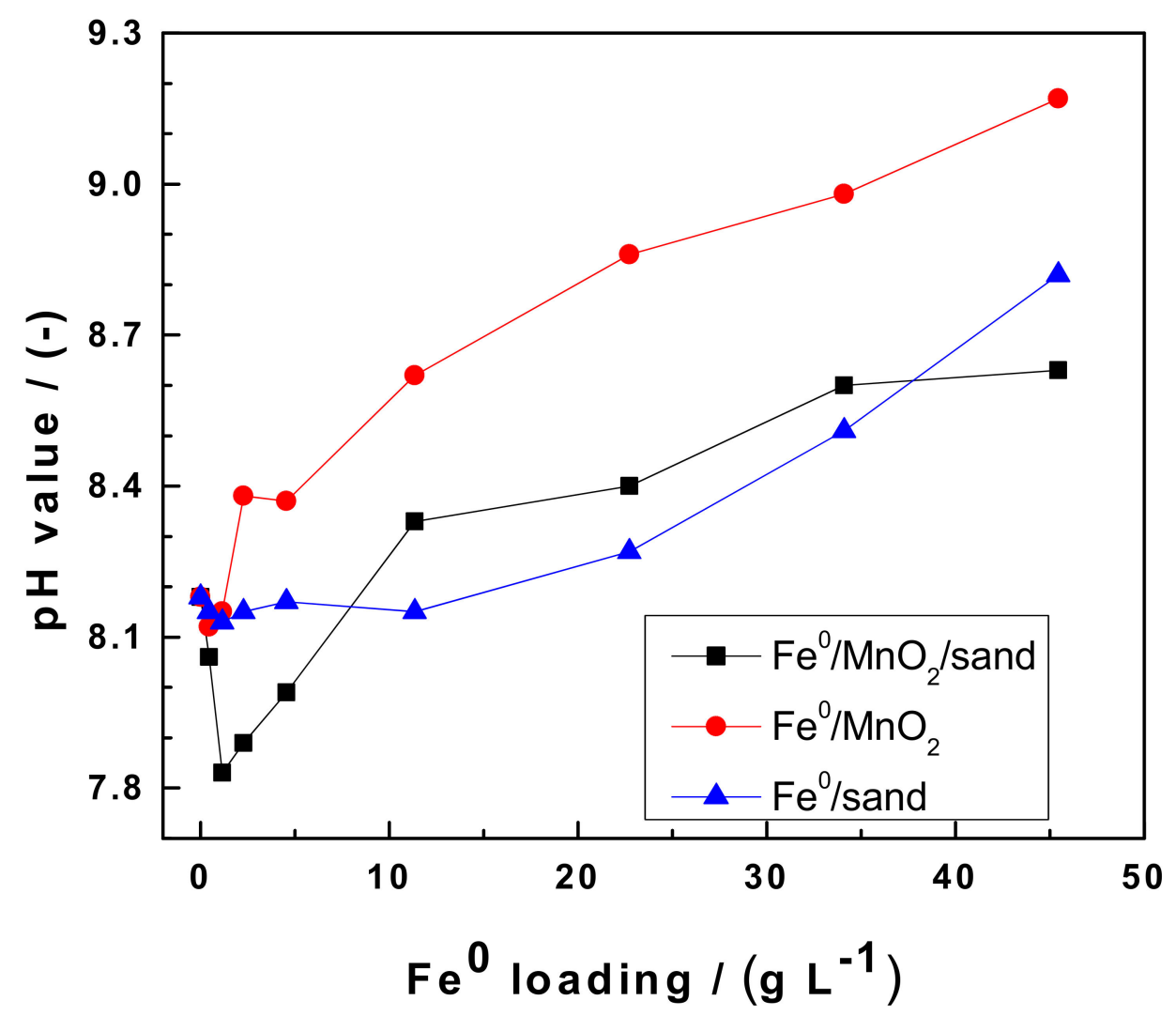

Figure 3. $\mathrm{pH}$ value in $\mathrm{Fe}^{0}$ / sand $/ \mathrm{MnO}_{2}$ systems as impacted by the addition of various $\mathrm{Fe}^{0}$ loading for 7 days. Experimental conditions: $\left[\mathrm{Fe}^{0}\right]=2.3$ to $45 \mathrm{~g} \mathrm{~L}-1$; [sand] $=45 \mathrm{~g} \mathrm{~L}-1$; and $\left[\mathrm{MnO}_{2}\right]=2.3 \mathrm{~g} \mathrm{~L}-1$, shaken intensity: $75 \mathrm{rpm}$. The lines are not fitting functions, they simply connect points to facilitate visualization.

\subsection{The Operating Mode of $\mathrm{Fe}^{0} / \mathrm{MnO}_{2}$ Systems}

The efficiency of $\mathrm{Fe}^{0} / \mathrm{H}_{2} \mathrm{O}$ systems for water decontamination relies primarily on the electrochemical corrosion of $\mathrm{Fe}^{0}$ by water (Equation (1)). This oxidative dissolution is followed by a series of chemical reactions in the vicinity of the $\mathrm{Fe}^{0}$ surface yielding to the formation of an oxide scale which is known as passive film $[1,3]$. The enhanced efficiency of $\mathrm{Fe}^{0} / \mathrm{MnO}_{2} / \mathrm{H}_{2} \mathrm{O}$ systems compared to their $\mathrm{Fe}^{0} / \mathrm{H}_{2} \mathrm{O}$ counterparts has been correctly justified by sustained generation of native FeCPs for contaminant adsorption and co-precipitation. However, the further interpretation of achieved results were speciesdependent. For example, Bui et al. [26] considered that there are oxidative species like $\mathrm{OH}$ radicals in the system to oxidize $\mathrm{As}^{\mathrm{III}}$ to $\mathrm{As}^{\mathrm{V}}$ with better adsorptive affinities to $\mathrm{FeCPs}$. This explanation becomes speculative when one considers that quantitative removal of Se which has also been documented [27], premised the reduction of $\mathrm{Se}^{\mathrm{VI}}$ to $\mathrm{Se}^{\mathrm{VI}}$. By using MB 
as operational tracer for the availability of $\mathrm{FeCPs}$ in investigated systems, this study has elegantly explained the operating mode of the $\mathrm{Fe}^{0} / \mathrm{MnO}_{2} / \mathrm{H}_{2} \mathrm{O}$ system.

By adding sand to the system as per the MB method $[15,16]$, this study has thoroughly characterized $\mathrm{MB}$ discoloration in the $\mathrm{Fe}^{0} / \mathrm{MnO}_{2} /$ sand $/ \mathrm{H}_{2} \mathrm{O}$ system. Changes of the $\mathrm{E}$ and $\mathrm{pH}$ values clearly show that sand is coated in situ by $\mathrm{FeCPs}$ and thus, can be regarded as storage room for fresh $\mathrm{FeCPs}$, avoiding their accumulation in the $\mathrm{Fe}^{0}$ vicinity and thus, delaying $\mathrm{Fe}^{0}$ passivation. $\mathrm{Fe}^{0}$ passivation is also delayed by two major factors attributed to the presence of $\mathrm{MnO}_{2}$ : (i) consumption of $\mathrm{Fe}^{2+}$ for the $\mathrm{MnO}_{2}$ reductive dissolution (Equation (3)) [28], and (ii) disturbance of the generation of "protective" oxides by virtue of the presence of $\mathrm{Mn}^{2+}$ ions.

The discussion of the chemistry of the $\mathrm{Fe}^{0} / \mathrm{MnO}_{2} / \mathrm{H}_{2} \mathrm{O}$ systems has excluded the formation of galvanic cells between $\mathrm{Fe}^{0}$ and $\mathrm{MnO}_{2}$ as a reason for enhanced efficient of $\mathrm{Fe}^{0} / \mathrm{H}_{2} \mathrm{O}$ systems through $\mathrm{MnO}_{2}$ amendment. Given that the reductive transformation of any dissolved species by electrons from the metal body is impossible $[18,19,29]$, this study established that adding $\mathrm{MnO}_{2}$ to $\mathrm{Fe}^{0} / \mathrm{H}_{2} \mathrm{O}$ systems should be regarded as creating a reactive $\mathrm{Fe} / \mathrm{Mn}$ mineral mixture. The geochemistry of such mixtures is well-known to geochemists $[9,10,30,31]$. However, their suitability for decontaminating engineered systems is yet to be systematically investigated [30,31].

Finally, the working hypotheses shall be tested: (i) $\mathrm{MnO}_{2}$ influences contaminant removal via adsorption, catalysis, co-precipitation and redox activities (Assertion 1), and $\mathrm{MnO}_{2}$ participates in the oxidation of selected contaminants (Assertion 2). Both assertions are valid as the MB method is just like a "separation of variables" enabling to trace the availability of native FeCPs which are Fe minerals. The mixture of Fe and Mn minerals is a reactive system that shall be tested for several contaminants and groups of contaminants to prepare for the advent of sustainably engineered $\mathrm{Fe}^{0} / \mathrm{MnO}_{2}$ systems.

\section{Conclusions}

The MB method proved to accurately describe the complexity of the $\mathrm{Fe}^{0} / \mathrm{MnO}_{2} /$ sand system. In particular, despite the absence of chemical, mineralogical/structural and morphological characterization of used aggregates, this method sufficiently described the dynamics within the named system. The uniqueness of the MB method is its simplicity and its affordability as only a UV sprectrophotometer is needed. The method can be adapted to all $\mathrm{Fe}^{0}$-based systems. However, it should be carefully considered that site-specific experiments with relevant contaminants are still unavoidable. This is because the affinity of individual contaminants to FeCPs depends on its speciation as well. The major output of this research is that $\mathrm{MnO}_{2}$ sustains $\mathrm{Fe}^{0}$ corrosion and thus the decontamination efficiency of $\mathrm{Fe}^{0} / \mathrm{H}_{2} \mathrm{O}$ systems. Thus adding, calculated amounts of well-characterized $\mathrm{MnO}_{\mathrm{x}}$ minerals to $\mathrm{Fe}^{0}$ filters is one highway to more sustainable filtration systems. In exploring this avenue, the reactivity of used aggregates should receive particular attention.

Author Contributions: G.A., V.C., N.G.-B. and C.N. conceived the presented idea and developed the theory. G.A. carried out the experiment. C.N. supervised this work. W.G. supervised the redaction of the first draft by V.C. and N.G.-B. All authors discussed the results and contributed to the final manuscript. All authors have read and agreed to the published version of the manuscript.

Funding: This research received no external funding.

Institutional Review Board Statement: Not applicable.

Informed Consent Statement: Not applicable.

Data Availability Statement: Not applicable.

Acknowledgments: For providing the iron material investigated in this study the authors would like to express their gratitude to iPutec $\mathrm{GmbH}$ (Rheinfelden, Germany). The natural $\mathrm{MnO}_{2}$-mineral was provided by the Department of Geology of the Technical University Bergakademie Freiberg/Germany (Mineralsammlung). The manuscript was improved by the insightful comments of anonymous 
reviewers from Processes. We acknowledge support by the German Research Foundation and the Open Access Publication Funds of the Göttingen University.

Conflicts of Interest: The authors declare no conflict of interest.

\section{References}

1. Guan, X.; Sun, Y.; Qin, H.; Li, J.; Lo, I.M.C.; He, D.; Dong, H. The limitations of applying zero-valent iron technology in contaminants sequestration and the corresponding countermeasures: The development in zero-valent iron technology in the last two decades (1994-2014). Water Res. 2015, 75, 224-248. [CrossRef] [PubMed]

2. Antia, D.D.J. Water treatment and desalination using the eco-materials n-Fe0 (ZVI), n- $\mathrm{Fe}_{3} \mathrm{O}_{4}, \mathrm{n}^{-} \mathrm{Fe}_{\mathrm{x}} \mathrm{O}_{\mathrm{y}} \mathrm{H}_{\mathrm{z}}\left[\mathrm{mH} \mathrm{m}_{2} \mathrm{O}\right]$, and $\mathrm{n}$ $\mathrm{Fe}_{\mathrm{x}}$ [Cation] $\mathrm{nO}_{\mathrm{y}} \mathrm{H}_{\mathrm{z}}$ [Anion]m [ $\left.\mathrm{rH}_{2} \mathrm{O}\right]$. In Handbook of Nanomaterials and Nanocomposites for Energy and Environmental Applications; Kharissova, O.V., Ed.; Springer Nature: Berlin/Heidelberg, Germany, 2020.

3. Thakur, A.K.; Vithanage, M.; Das, D.B.; Kumar, M. A review on design, material selection, mechanism, and modelling of permeable reactive barrier for community-scale groundwater treatment. Environ. Technol. Innov. 2020, 19, 100917. [CrossRef]

4. Noubactep, C. Processes of contaminant removal in " $\mathrm{Fe}^{0}-\mathrm{H}_{2} \mathrm{O}^{\prime}$ systems revisited. The importance of co-precipitation. Open Environ. Sci. 2007, 1, 9-13. [CrossRef]

5. Bojic, A.L.; Bojic, D.; Andjelkovic, T. Removal of $\mathrm{Cu}^{2+}$ and $\mathrm{Zn}^{2+}$ from model wastewaters by spontaneous reduction-coagulation process in flow conditions. J. Hazard. Mater. 2009, 168, 813-819. [CrossRef]

6. Ghauch, A. Iron-based metallic systems: An excellent choice for sustainable water treatment. Freib. Online Geosci. 2015, 32, 1-80.

7. Gheju, M.; Balcu, I. Sustaining the efficiency of the $\mathrm{Fe}(0) / \mathrm{H}_{2} \mathrm{O}$ system for $\mathrm{Cr}(\mathrm{VI})$ removal by $\mathrm{MnO}_{2}$ amendment. Chemosphere 2019, 214, 389-398. [CrossRef] [PubMed]

8. Melchers, R.E.; Petersen, R.B. A reinterpretation of the Romanoff NBS data for corrosion of steels in soils. Corros. Eng. Sci. Technol. 2018, 53, 131-140. [CrossRef]

9. Huang, J.; Zhang, H. Redox reactions of iron and manganese oxides in complex systems. Front. Environ. Sci. Eng. 2020, 14, 76. [CrossRef]

10. Michel, M.M.; Reczek, L.; Papciak, D.; Włodarczyk-Makuła, M.; Siwiec, T.; Trach, Y. Mineral materials coated with and consisting of $\mathrm{MnO}_{\mathrm{x}}$ - Characteristics and application of filter media for groundwater treatment: A review. Materials 2020, 13, 2232. [CrossRef] [PubMed]

11. Hussam, A.; Munir, A.K.M. A simple and effective arsenic filter based on composite iron matrix: Development and deployment studies for groundwater of Bangladesh. J. Environ. Sci. Health A 2007, 42, 1869-1878. [CrossRef] [PubMed]

12. Liang, Y.; Min, X.; Chai, L.; Wang, M.; Liyang, W.; Pan, Q.; Okido, M. Stabilization of arsenic sludge with mechanochemically modified zero valent iron. Chemosphere 2017, 168, 1142-1151. [CrossRef]

13. Burghardt, D.; Kassahun, A. Development of a reactive zone technology for simultaneous in situ immobilisation of radium and uranium. Environ. Geol. 2005, 49, 314-320. [CrossRef]

14. Dong, G.; Huang, L.; Wu, X.; Wang, C.; Liu, Y.; Liu, G.; Wang, L.; Liu, X.; Xia, H.; Dong, G. Effect and mechanism analysis of $\mathrm{MnO}_{2}$ on permeable reactive barrier (PRB) system for the removal of tetracycline. Chemosphere 2018, 193, 702-710. [CrossRef] [PubMed]

15. Btatkeu-K, B.D.; Olvera-Vargas, H.; Tchatchueng, J.B.; Noubactep, C.; Caré, S. Characterizing the impact of $\mathrm{MnO}_{2}$ on the efficiency of $\mathrm{Fe}^{0}$-based filtration systems. Chem. Eng. J. 2014, 250, 416-422. [CrossRef]

16. Miyajima, K.; Noubactep, C. Characterizing the impact of sand addition on the efficiency of granular iron for water treatment. Chem. Eng. J. 2015, 262, 891-896. [CrossRef]

17. Alyoussef, G. Characterizing the Impact of Contact Time in Investigating Processes in $\mathrm{Fe}^{0} / \mathrm{H}_{2} \mathrm{O}$ Systems. Master's Thesis, University of Göttingen, Göttingen, Germany, 2016.

18. Whitney, W.R. The corrosion of iron. J. Am. Chem. Soc. 1903, 25, 394-406. [CrossRef]

19. Stratmann, M.; Müller, J. The mechanism of the oxygen reduction on rust-covered metal substrates. Corros. Sci. 1994, 36, 327-359. [CrossRef]

20. Xiao, M.; Cui, X.; Hu, R.; Gwenzi, W.; Noubactep, C. Validating the Efficiency of the FeS2 Method for Elucidating the Mechanisms of Contaminant Removal Using $\mathrm{Fe}^{0} / \mathrm{H}_{2} \mathrm{O}$ Systems. Processes 2020, 8, 1162. [CrossRef]

21. Appelo, C.A.J.; Postma, D. A consistent model for surface complexation on birnessite $\left(-\mathrm{MnO}_{2}\right)$ and its application to a column experiment. Geochim. Cosmochim. Acta 1999, 63, 3039-3048. [CrossRef]

22. Post, J.E. Manganese oxide minerals: Crystal structures and economic and environmental significance. Proc. Natl. Acad. Sci. USA 1999, 96, 3447-3454. [CrossRef]

23. Varlikli, C.; Bekiari, V.; Kus, M.; Boduroglu, N.; Oner, I.; Lianos, P.; Lyberatos, G.; Icli, S. Adsorption of dyes on Sahara desert sand. J. Hazard. Mater. 2009, 170, 27-34. [CrossRef] [PubMed]

24. Ndé-Tchoupé, A.I.; Makota, S.; Nassi, A.; Hu, R.; Noubactep, C. The Suitability of Pozzolan as Admixing Aggregate for Fe0-Based Filters. Water 2018, 10, 417. [CrossRef]

25. Mitchell, G.; Poole, P.; Segrove, H.D. Adsorption of methylene blue by high-silica sands. Nature 1955, 176, 1025-1026. [CrossRef]

26. Bui, T.H.; Kim, C.; Hong, S.P.; Yoon, J. Effective adsorbent for arsenic removal: Core/shell structural nano zero-valent iron/manganese oxide. Environ. Sci. Pollut. Res. 2017, 24, 24235-24242. [CrossRef] 
27. Qin, H.; Sun, Y.; Yang, H.; Fan, P.; Qiao, J.; Guan, X. Unexpected effect of buffer solution on removal of selenite and selenate by zerovalent iron. Chem. Eng. J. 2018, 334, 296-304. [CrossRef]

28. Sanjeev, B.; Malay, C. Removal of arsenic from ground water by manganese dioxide-coated sand. J. Environ. Eng. 1999, 125, 782-784.

29. Noubactep, C. Metallic iron for environmental remediation: A review of reviews. Water Res. 2015, 85, 114-123. [CrossRef]

30. Brock, S.L.; Duan, N.; Tian, Z.R.; Giraldo, O.; Zhou, H.; Suib, S.L. A review of porous manganese oxide materials. Chem. Mater. 1998, 10, 2619-2628. [CrossRef]

31. Dong, G.; Han, R.; Pan, Y.; Zhang, C.; Liu, Y.; Wang, H.; Ji, X.; Dahlgren, R.A.; Shang, X.; Chen, Z.; et al. Role of MnO 2 in controlling iron and arsenic mobilization from illuminated flooded arsenic-enriched soils. J. Hazard. Mater. 2021, 401,123362 [CrossRef] 